Western University Scholarship@Western

Centre for the Study of International Economic

Centre for the Study of International Economic

Relations Working Papers

Relations

1986

\title{
The Design of Contracts: Evidence from Japanese Subcontracting
}

Seiichi Kawasaki

John McMillan

Follow this and additional works at: https://ir.lib.uwo.ca/economicscsier_wp

Part of the Economics Commons

Citation of this paper:

Kawasaki, Seiichi, John McMillan. "The Design of Contracts: Evidence from Japanese Subcontracting." Centre for the Study of International Economic Relations Working Papers, 8607C. London, ON: Department of Economics, University of Western Ontario (1986). 
THE CENTRE FOR THE STUDY OF INTERNATIONAL ECONOMIC RELATIONS

WORKING PAPER NO. $8607 \mathrm{C}$

THE DESIGN OF CONTRACTS :

EVIDENCE FROM JAPANESE SUBCONTRACTING

\author{
Seiichi Kawasaki \\ and \\ John McMillan
}

This paper contains preliminary findings from research work still in progress and should not be quoted without prior approval of the authors.

DEPARTMENT OF ECONOMICS

THE UNIVERSITY OF WESTERN ONTARIO Departunent of Esosonics Library LONDON, CANADA

N6A 5 C 2

MAR 141986

University of Western Ontario 
THE DESIGN OF CONTRACTS:

EVIDENCE FROM JAPANESE SUBCONTRACTING ${ }^{*}$

Sei.ichi Kawasaki and John McMillan

Ritsumeikan University, Japan University of Western Ontario, Canada

Revised: March 1986

\section{Abstract}

This paper investigates the design of contracts in a principal-agent framework, using data from Japanese subcontracting. The data show the following. First, the subcontractors are risk averse. Second, the contracts have the principal absorbing some of the risk on behalf of the subcontractor. Third, the price adjusts more to changes in the subcontractor's production costs (i) the more risk averse the subcontractor; (ii) the bigger the fluctuations in costs; and ( $i i i)$ the less severe the moral hazard. Thus the contracts in use in Japanese subcontracting can be interpreted as resolving the principal-agent tradeoff between risk sharing and moral hazard.
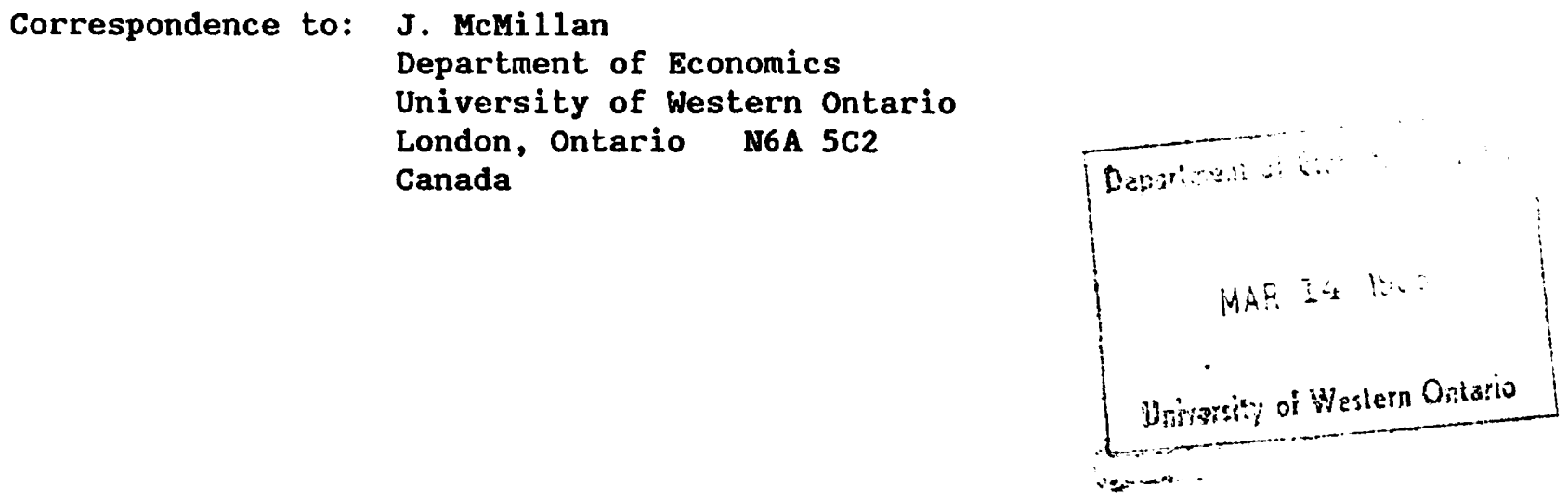


\section{Introduction}

Much recent research in microeconomic theory has been concerned with the design of contracts, solving problems that arise because of asymmetries of information. How do actual markets solve these problems in practice?

\section{Subcontracting versus Vertical Integration}

One of the conspicuous features of the Japanese economy is the extent to which the major firms subcontract their production requirements to smaller firms. According to the Ministry of International Trade and Industry (MrTI), "Japanese manufacturing industry owes its competitive advantage and strength to its subcontracting structure." 1 In Japan, there are four times as many wholesale transactions as retail transactions; in the United states, Britain and West Germany, by contrast, the ratio of wholesale to retail transactions is between 1.6 and 1.9 . In the Japanese automobile industry, an average of 75 percent of a car's value is provided by outside suppliers, and only 25 percent is produced within the firm; in the U.S. automobile industry, 55 percent is provided by outside suppliers. ${ }^{2}$

When a firm chooses to produce its inputs itself instead of buying them from outside suppliers, it substitutes a nonmarket means of allocating resources for the price system. Thus in this respect, contrary to the conventional wisdom, the Japanese economy makes more use of the market mechanism than does the U.S. economy. Moreover, the amount of subcontracting in Japanese manufacturing industry is increasing over time, ${ }^{3}$ contradicting the thesis of Chandler (1977) that the trend in modern economies is towards increasingly vertically integrated production. 
One of the fundamental questions in economics is: What are the limits of the market? What determines which transactions occur within a firm and which are controlled by the price system? (Coase (1937).) Any answer to this question obviously must compare the operation of the market with the internal workings of the firm. In practice, the answer seems to vary from economy to economy: as just noted, Japanese firms use subcontracting rather than vertical integration to a greater extent than firms in the U.S. and Europe. This study will examine some market transactions which, by their nature, could instead have been carried out within a vertically integrated firm (and probably many of them would have been in any economy other than Japan's). Evidently, in the Japanese case, the market solution copes with the problems of coordination and control at least as successfully as hierarchical direction within a firm would have (indeed, according to MITI (1984), it works better). There is a semantic issue of whether the subcontracting relationship ought to be regarded as a market relationship. Imai and Itami (1984), for example, argued that the Japanese subcontracting system is not a pure market mechanism but is something uniquely Japanese, intermediate between the market and vertical integration. 4 We, however, find useful the clearcut dichotomy, implied by the title of Williamson's 1975 book, between markets and hierarchies. Contracting firms own only a small fraction, if any, of their subcontractors' stock: they are separate companies. The fact that a pair of firms has a longstanding relationship, the existence of which generates rents for both firms, does not mean that their relationship is a nonmarket one: ongoing relationships are common in both product markets and labor markets everywhere (see Okum (1980) and wilson (1983) for some examples). Subcontracting involves price-mediated exchange between independent economic agents; this seems to conform to any reasonable definition of market exchange. 
This paper uses data on Japanese subcontracting to investigate the nature of contracts under asymmetric information. The analysis to follow will show that Japanese subcontracting practices can be understood as the outcome of rational, self-interested behavior ${ }^{5}$.

\section{Equilibrium Contracts under Asymetric Information}

often, one party to an exchange knows something relevant to the transaction that the other party does not know. For example, the seller is likely to be better informed than the buyer about production costs. Such asymmetries of information can give rise to problems of moral hazard: the buyer cannot be sure whether the supplier is exerting enough effort to hold down his production costs.

The equilibrium contract must recognize the incentive problems posed by informational asymmetries. To complicate the issue, if the buyer and the seller differ in their degrees of risk aversion, it is in their mutual interest to share the burden of uncertainty. This means that the equilibrium contract may involve tradeoffs. In particular, if the supplier is more risk averse than the buyer, the supplier would be willing to accept a lower price in exchange for the buyer's willingly bearing some of the risk of unpredictable production-cost increases. But once the supplier is no longer fully responsible for the costs he incurs, his incentives to exert effort to hold down his production costs are weakened.

With asymmetric information, therefore, the equilibrium contract is likely to be more complex than the simple fixed-price contract considered in traditional economic theory. Moreover, the best feasible contract must necessarily be inferior to what could be achieved if information were perfect (MacDonald (1984)). 
The following principal-agent model will be used as the basis for the empirical analysis. The model is a special case of the models of Holmstrom and Milgrom (1985) and McAfee and McMillan (1985).

A principal wishes to have a task performed by a subcontractor. The principal acts as first mover: he is able to commit himself in advance to a particular payment function. In this sense, the principal is assumed to have more bargaining power than the subcontractor.

Assume that the principal, being large, is risk neutral towards the outcome of this particular contract (or, equivalently, is no more risk averse than the subcontractor). The subcontractor may be either risk averse or risk neutral. Note that what is relevant here are the two firms' attitudes towards the risks associated with one particular contract. Thus it may be that the principal is, in overall terms, equally as risk-averse as the subcontractor. However, the principal is a larger firm than the subcontractor. The fluctuations associated with this single contract are so small relative to the principal's total profit as to be insignificant, so that his utility is approximately linear in profits from this contract. For the subcontractor, in contrast, this contract's profit fluctuations may significantly change his total profit, in which case the curvature of his utility function does affect his actions with respect to this contract. In other words, towards a particular contract, the principal behaves as if he is risk neutral, whereas the subcontractor's behavior reflects his degree of risk aversion.

The subcontractor is assumed to have a constant-absolute-risk-aversion utility function

$$
U(\pi)=\frac{1-e^{-\lambda \pi}}{\lambda},
$$


where $\pi$ represents profit and $\lambda \geq 0$ is the Arrow-Pratt measure of absolute risk aversion.

As in Holmstrom and Milgrom (1985), assume that the subcontractor's production activities take place in continuous time, but that the principal pays the subcontractor only at discrete points in time. The payment is based on the accumulated production costs up to the time of payment. The subcontractor's production costs fluctuate randomly, but the subcontractor is able, with costly effort, partially to control his production costs. Specifically, it is assumed that production costs follow a Brownian motion, of which the subcontractor controls the drift. The Brownian motion results in the accumulated production cost at the time of payment being normally distributed. Holmstrom and Milgrom (1985) proved the strong result that the optimal contract is linear in end-of-period accumulated production costs: this dynamic principal-agent problem can be solved as if it were a static problem with the additional restriction that the payment function is linear. 6

We now solve the corresponding static problem, following both Holmstrom and Milgrom (1985) and McAfee and McMillan (1985). Represent the principal's optimal payment function by

$$
p=b+\alpha(c-b),
$$

where $p$ is the price paid, $c$ is the accumulated production cost, and $a$ and $b$ are parameters chosen in advance by the principal. The parameter $b$ is a target price; if $c$ exceeds $b$ there is a cost overrun, while if $b$ exceeds $c$ there is a cost underrun. The sharing parameter, $\alpha$, determines how cost overruns and underruns are to be shared. If $\alpha=0$, the contract is fixed-price; all of the risk of cost fluctuations is borne by the subcontractor. If $\alpha=1$, the contract is cost-plus; the principal bears the entire risk. If $0<\alpha<1$, the risk is shared; the contract is an incentive contract. 
The subcontractor's accumulated production cost, upon which the principal bases his payment, has three components:

$$
c=c^{\star}+w-\xi \text {. }
$$

Here $c^{*}$ represents the subcontractor's ex ante expected cost. The subcontractor and the principal know the value of $c^{\star}$. The term $w$ is a random variable representing unpredictable cost fluctuations observed only by the subcontractor in the course of doing the work. Although he cannot observe the realization of $w$, the principal does know its distribution, which, as already noted, we assume to be normal, with mean zero and variance $\sigma^{2}$.

The third term in the cost function, $\xi$, represents the reduction in cost achieved as a result of the subcontractor's cost-controlling effort. This effort is costly to the subcontractor: it costs the subcontractor an amount $h(\xi)$ in dollar terms. In particular, we assume $h(\xi)$ is quadratic:

$$
h(\xi)=\frac{\xi^{2}}{2 \delta},
$$

for some $\delta>0$. The principal cannot directly observe the level of the subcontractor's cost-controlling effort and, because the principal cannot observe the realization of the random variable $w$, he cannot deduce the subcontractor's effort from his observation of the total cost c. Thus there is moral hazard. Since the principal cannot know the subcontractor's level of effort, he cannot make his payment contingent upon it; he cannot directly reward the subcontractor for his cost-controlling activities. The cost-reducing effort $\xi$ could consist of a variety of activities including, for example, searching for lower-priced inputs, or resisting labor-union demands for higher wages, or carefully managing raw-material or final-goods inventories so that excessive costly stocks are not being held. ${ }^{8}$ The costs to the subcontractor of these activities, which he cannot charge to the project, are summarized by the function $h$. 
To solve for the equilibrium contract, we first find the subcontractor's optimal response to any particular contract offered by the principal. Take the quantity ordered to be exogenous (it is determined by the final demand for the principal's product, and this contract makes up only a small fraction of the principal's costs). By appropriate choice of units, this order quantity can be set equal to one. The subcontractor's production cost consists of the cost he charges to the project plus the cost of effort (which is unobservable to the principal). Using the expression (3) for the observable cost c, adding the cost of effort $h(\xi)$, and subtracting this total from the payment (2) gives the subcontractor's profit $\pi$ :

$$
\pi=(1-\alpha)\left(b-c^{*}-w+\xi\right)-h(\xi) .
$$

The subcontractor may observe the random variable $w$ either before or after choosing his level of effort $\xi$. Maximizing expected utility of profit, the subcontractor will choose a level of effort (using (4) and (5)):

$$
\xi=\delta(1-\alpha) \text {. }
$$

Thus effort decreases as a increases. The larger is $\alpha$, the less the subcontractor is responsible for his own costs and so the weaker is his incentive to undertake cost-reducing activity (which is costly to him). Note that, from (6) and (3), the difference between production cost under a cost-plus contract $(\alpha=1)$ and production cost under a fixed-price contract $(\alpha=0)$ is equal to $\delta$. Hence $\delta$ provides a natural measure of the extent of moral hazard.

If the contract is anything other than fixed price (so that $\alpha>0$ ), it has the effect of shifting some of the risk of cost fluctuations onto the principal and thereby of reducing the variance of the subcontractor's profits, $s^{2}$, below the variance of his cost fluctuations, $\sigma^{2}$. Given that the target 
price $b$ is fixed in advance, (5) implies

$$
s^{2}=(1-\alpha)^{2} \sigma^{2} \text {. }
$$

Since cost and profit are linearly related (by (5)), the assumption that the subcontractor's cost fluctuations are normally distributed implies that his profits are also normally distributed: represent by $\mu$ the mean of the subcontractor's profit. Constant absolute risk aversion together with normality of profit disturbances imply that the subcontractor's expected utility of profit is

$$
\operatorname{EU}(\pi)=\frac{1-\exp \left(-\lambda \mu+1 / 2 \lambda^{2} s^{2}\right)}{\lambda} .
$$

Thus these functional-form assumptions ensure that expected utility is a function of a function that is linear in mean and variance, which is commonly assumed in empirical analyses of risk attitudes (and which will be used in Section 6 below in estimating the subcontractors' degrees of risk aversion).

Turn now to the principal's optimization problem. The choice of the contract (2) is essentially the choice of the sharing parameter $\alpha$, since, as will be seen, once $\alpha$ is determined, the other contract parameter $b$ is also determined. The principal can predict that the subcontractor will respond to the contract $\alpha$ according to (6). Thus the principal's optimal contract is found by minimizing the expected value of the principal's payment (2) subject to two constraints: first, the subcontractor responds by choosing his optimal cost-controlling effort so that (6) is satisfied; second, the subcontractor has the option of refusing to accept the contract offer and so the subcontractor's expected utility must be no less than his expected utility from his best alternative activity (which is taken to be given exogenously). This results in the following first-order condition for the principal's optimal choice of $\alpha:^{9}$ 


$$
\alpha=\frac{\lambda \sigma^{2}}{\delta+\lambda \sigma^{2}} .
$$

This equation will be tested in the econometric analysis to follow. Note that it implies that the chosen level of $\alpha$ satisfies $0 \leq \alpha \leq 1$ and is:

(i) decreasing in the measure of moral hazard $\delta$;

(ii) increasing in the variance of the cost disturbance $\sigma^{2}$;

(iii) increasing in the risk-aversion coefficient $\lambda$.

All of these results are consistent with intuition. (It should be noted, however, that, if optimal contract were nonlinear, these comparative-statics properties would not hold in general: see MacDonald (1984).)

\section{Contracts in the Japanese Automobile Industry}

An interesting series of case studies of subcontracting in the Japanese automobile industry has been provided by Asanuma (1984a, 1984b, 1985). Asanuma interviewed executives of six car makers and six independent part suppliers. His $\mathrm{findings}$ about the nature of the contracts in use can be summarized in the light of the foregoing model as follows. 10

A typical model of automobile is produced over a four-year period. A contract with a parts supplier for the production of a particular component is written for the duration of the model. The car maker guarantees not to switch suppliers or to start producing the item himself within this period. (Indeed, frequently the same supplier is contracted with from model to model, although not without having his performance compared with his competitors' performance.)

The contract agreed upon at the start of a four-year period does not specify firm quantities. Instead, the car maker specifies target quantities and delivery dates, which he is not, however, bound to meet. 
Rather than specify a firm price, the contract specifies the rules by which the price is to be determined. An initial unit price is established in the contract as the basis for price calculations. This initial price is determined on the basis of detailed cost estimates submitted by the subcontractor and carefully examined by the car maker. (This initial price corresponds to the parameter $b$ in the payment function (2).) Then every six months the price can be adjusted in response to the subcontractor's production-cost changes.

Since there is usually a long-run relationship between the car maker and the subcontractor, the car maker may be presumed to acquire over time an accurate knowledge of the subcontractor's production function (which amounts to knowing the expected cost $c^{\star}$ in the cost expression (3)). He cannot, however, have perfect knowledge about cost fluctuations (that is, the random variable $w$ in $(3))$. How does the car maker verify the subcontractor's cost statements (about the total cost $c$ in (3))? There are two methods. With a small subcontractor undertaking a simple manufacturing process of only a few production stages, the car maker inspects the subcontractor's factory and does time-and-motion studies. With more complicated manufacturing processes, the car maker whenever possible uses multiple suppliers for each individual part; thus one subcontractor's claims about costs can be checked by comparing them with another subcontractor's. (This practice of multiple sourcing presumably has other incentive effects which will not be examined in this paper.)

In adjusting the price, the subcontractor's labor, materials, and energy costs are considered separately. While the car maker will allow an increase in the cost of materials to be passed on as a price increase, he is less ready to agree to passing on increases in labor and energy costs. In addition, 
there are provisions in the contract for changing the price in response either to cost changes resulting from design changes made by the car maker or to cost reductions due to the subcontractor's rationalization.

These rules for adjusting price are more sophisticated than in the principal-agent model of section 3 , in that they are based on a vector of cost components instead of a single overall cost observation. They may, however, be consistent with that model. Asanuma concluded from his case studies that a risk-sharing mechanism operates between the car maker and its suppliers. It is possible that the overall effect of one of these contracts is as if the price were determined by some sharing parameter $\alpha$ (with $0 \leq \alpha \leq 1$ ) applied to the subcontractor's total costs. The next three sections provide an empirical test of the model of section 3 .

\section{The Sharing Parameter}

In order to test directly the predictions of the principal-agent model of Section 3, much detailed micro-level data about the precise terms of contracts would have to be collected. Not surprisingly, such data are unavailable (in part because of the firms' confidentiality requirements). It is possible, however, to manipulate the model into a form which allows us to use standard aggregated industry data to make inferences about the average characteristics of the contracts in use.

In the model of section 3 , if the contract is anything other than fixedprice (so that $\alpha>0$ ), it has the effect of shifting some of the risk of cost fluctuations onto the principal and thereby of reducing the variance of the subcontractor's profits, $s^{2}$, below the variance of his cost fluctuations, $\sigma^{2}$. Equation (7) shows that (since, from (9), $0 \leq \alpha \leq 1$ ) the ratio of the subcontractor's profit variance to cost variance is decreasing in $\alpha$. This is 
the crucial observation: it shows that the effects of the choice of sharing parameter $\alpha$ can be estimated without detailed data on individual contracts. Rearrange equation (7):

$$
\alpha=1-\frac{s}{\sigma}
$$

where $s$ and $\sigma$ represent the standard deviations of profit and cost. We estimated $s$ and $\sigma$ from aggregated data with firms classified by industry and firm size. (See the appendix for the data sources and the details of the estimation of the standard deviations.) We then used equation (10) to calculate the value of a used by firms in each category. Since the data are aggregated, each calculated a should be interpreted as being both averaged over the firms within the particular category and, insofar as one firm may have more than one contract, averaged over each firm's different contracts. 11 The computed sharing parameters $\alpha$ are reported in Table 1: they range between 0.39 and 0.89 .

In interpreting the calculations of the sharing parameter $\alpha$, recall that a fixed-price contract (which gives the subcontractor strong incentives to hold down his costs but requires him to bear all of the risk) has $\alpha=0$; while a cost-plus contract (which leaves the subcontractor bearing no risk but offers him no incentive to keep costs low) has $\alpha=1$. The principal-agent model of Section 3 predicts that the $\alpha$ 's satisfy $0 \leq \alpha \leq 1$.

Table 1 provides a simple test of the principal-agent model. clearly any a computed using equation (10) must be less than one; it need not, however, be nonnegative. Equation (10) would generate a negative $\alpha$ if a firm's profit variance exceeded its cost variance. As an alternative to the model of Section 3, consider a more conventional model of a competitive firm, facing both cost and demand uncertainty, which must set either output or price in advance of the resolution of the uncertainty (such as in Lim (1981)). The 
variance of profits would exceed the variance of costs unless revenues and costs were positively correlated. In an arbitrarily-selected set of firms behaving in this way, one would expect to find the demand variability often reinforcing the cost variability with the result that many of the $\alpha$ 's computed using equation (10) would be negative. In the absence of an institution which systematically absorbs some of the firm's risks, there is no reason to suppose that the profit variance is less than the cost variance. The principal-agent contracts examined in section 3 are designed to absorb the subcontractor's cost risks. Thus the fact that all 45 of the $\alpha$ 's in Table 1 are clearly positive (as already noted, the smallest $\alpha$ is 0.39 ) shows that the firms in our sample are systematically avoiding part of the risk of their cost fluctuations; these observations are therefore consistent with the principal-agent model of section 3.

It is interesting to note that most of the contracts implied by Table 1 are closer to the cost-plus end of the contract spectrum than to the fixed-price end. (Only 5 of the 45 calculated $\alpha^{\prime}$ 's are less than $0.5 ; 19$ of the 45 exceed 0.75 ; their unweighted average is 0.69. ) In some (imprecise) sense, the contracts seem to be designed more to share risk than to give the subcontractor appropriate incentives. Two explanations for this can be of fered.

One explanation comes from the fact that, at the end of a contract term, the principal often offers a further contract to the subcontractor. A survey of subcontracting firms reported by Yokokura (1984) found that 84 percent had not had a change of principal in the previous five years. Lewis (1980) showed that a continuous payment function such as given by equation (2) is dominated by a payment scheme which involves a lump-sum penalty. The penalty reduces the agent's incentive to shirk. Thus the continuous part of the contract can be used to provide more risk sharing; that is, the addition of the penalty 
allows the sharing parameter $\alpha$ to be closer to unity. The principal's ability to break off his relationship with the subcontractor acts like a lump-sum penalty. The subcontractor is given an additional incentive to hold down his production costs in the current contract because he knows his effort will be rewarded by an increased probability of receiving future profitable contracts.

Another explanation for the sharing parameter a tending to be close to one is that, as McAfee and McMillan (1985) showed, the contract terms can serve a third purpose, in addition to sharing risk and giving cost-control incentives. If there is a market for subcontractors' services, and if competition in that market is less than perfect, then the principal can use the contract terms to stimulate bidding competition among the potential subcontractors. The larger is the sharing parameter $\alpha$, the more aggressive is the induced bidding competition. Asanuma (1985), in his case study of the Japanese automobile industry, found that the competition for any particular contract is typically confined to a small number of firms: according to the analysis of McAfee and McMillan (1985), this would by itself tend to cause the principal to set the sharing parameter close to one. However, this effect will not be examined in the following empirical test for lack of data on bidding competition.

\section{Are the Subcontractors Risk Averse?}

The model of Section 3 has a trivial solution if the subcontractor is risk neutral: namely, the equilibrium contract is fixed-price, so that the subcontractor bears all of the risk (since, from equation ( 9 ), $\alpha=0$ if $\lambda=0$ ). It is not self-evident that firms must be risk averse. Thus, in this section, we address the question of whether the subcontractors in the sample 
are risk averse or risk neutral. Using the assumptions already built into the model of Section 3, estimates of the firms' degrees of risk aversion can be obtained as follows.

Assume that expected utility $E U\left(\pi_{i}\right)$ is the same for all subcontracting firms within a given category i. Equation ( 8 ), which embodies the assumptions of constant absolute risk aversion and normality of disturbances, can then be rearranged to yield a linear relationship between mean and variance of profits:

$$
\mu_{i j}=\left(1 / 2 \lambda_{i}\right) s_{i j}^{2}+k_{i} \text {, }
$$

where $\mu_{i j}$ and $s_{i j}^{2}$ are the mean and variance of profits for the $j^{\text {th }}$ firm of type $i$ and

$$
k_{i}=-\frac{1}{\lambda_{i}} \ln \left(1-\lambda \operatorname{EU}\left(\pi_{i}\right)\right) .
$$

Note that, from (12), $k_{i}=0$ if and only if $\operatorname{EU}\left(\pi_{i}\right)=0$.

Equation (11) can be estimated. The signs of the estimated coefficients are predicted to be $\lambda \geq 0$ and $k \geq 0$. A test of the hypothesis that $\lambda=0$ serves to test the claim that the firms in the sample are risk neutral. A test of the hypothesis that $k=0$ tests whether the subcontractors are on average earning zero expected utility. ${ }^{12}$ We estimated equation (11) by ordinary least squares using aggregated data with firms classified by industry and by firm size. (See the appendix for data sources and details of the profit-variance estimates.) ${ }^{13}$

Consider the estimates of risk aversion reported in Table 2. Recall from equation (11) that the coefficient of the profit variance is $\lambda / 2$, where $\lambda$ is the coefficient of absolute risk aversion. Thus, from Table 2, the estimated risk-aversion coefficient ranges from 0.30 (for firms with 20 to 29 employees) to 0.003 (for firms with 200 to 299 employees). Estimated risk aversion 
monotonically declines with firm size (as it should on theoretical grounds). In all cases, the estimated risk-aversion coefficient is significantly larger than zero: the subcontractors are not risk neutral.

The estimated risk-aversion coefficient of the firms with 20 to 29 employees indicates a large amount of risk aversion. Consider a gamble yielding a payoff of either $\$ 10$ or zero, each with probability 0.5 . An economic agent with a risk-aversion coefficient of 0.003 would pay $\$ 4.93$ to participate in this gamble, close to a risk-neutral agent's \$5. However, an agent with a risk-aversion coefficient of 0.3 would pay only $\$ 1.58$.

The estimated degree of risk aversion for the smallest firms therefore seems implausibly high. However, the main purpose of this section was not to estimate the size of risk aversion, but to test whether the subcontractors are risk neutral. We conclude from the foregoing estimates that the subcontractors are significantly risk averse. The principal-agent problem is therefore nontrivial.

The estimated constant terms $k$ in Table 2 represent the average risk-adjusted profits earned by the firms in each category (see equation (11)). In a frictionless free-entry equilibrium, $k$ would equal zero. The estimates indicate that, in all cases, $k$ significantly exceeds zero. Moreover, the estimated k's monotonically increase with firm size. Two alternative conclusions are possible. One the one hand, there may be forces at work preventing entrants from competing away these profits. One can find plausible explanations for Japanese subcontractors' earning persistently positive profits. A feature of this market is that relationships between particular principal-subcontractor pairs tend to continue over time: McMillan and Morgan (1984) showed that such ongoing relationships can generate rents for both firms which persist even in a free-entry equilibrium. Also, 
subcontractors often locate themselves near the firms for which they work; location-induced cost advantages over potential competitors might explain the incumbents' positive profits. On the other hand, it is accounting profit, not economic profit, that is measured in the data. It is possible that what is being picked up in the estimates of $k$ is the difference between accounting profit and economic profit. The risk-adjusted economic profit may actually be zero. Since the estimates of $k$ are irrelevant to the test of principal-agent theory, we shall not try to resolve this question. ${ }^{14}$

\section{Empirical1y Testing the Principal-Agent Model}

Section 5 , by showing that the computed sharing parameters clearly exceed zero, provided one test of the principal-agent model of Section 3 . In this section, we develop an econometric test of the model. We seek the determinants of variations in the sharing parameter $\alpha$. The equation to be estimated is (9), which (given that $0<\alpha<1$ ) can be rearranged into the linear form:

$$
\ln \left(\frac{1}{\alpha}-1\right)=\ln \left(\frac{1}{2}\right)+\ln \left(\frac{1}{\lambda}\right)+\ln \delta .
$$

The cost variance $\sigma^{2}$ has already been estimated and used in the foregoing analysis. We use proxies for the other two variables, the subcontractor's risk aversion $\lambda$ and the moral hazard $\delta$.

Since we estimated the risk-aversion coefficients $\lambda$ in section 6 , it would be possible to use these estimates as one of the independent variables in (13). We do this in one regression, but in another regression we replace $\lambda$ by a pair of proxy variables. This is because the $\lambda$ estimates are somewhat suspect: for example, they are based on the strong assumption that all firms of a given size earn the same expected utility. 
A subcontracting firm will tend to be less risk averse towards any particular project the smaller the project is relative to its overall operations. Thus one proxy for risk aversion is the total value of the firm's sales. Also, the firm will be less risk averse to any one project the more diversified its portfolio of projects is. Thus another proxy for risk aversion is the number of different firms for which the firm subcontracts. Ceteris paribus, risk aversion should decline as the firm's sales increase and as the number of firms for which it subcontracts increases.

Although moral hazard is represented in the theory by a single variable, $\delta$, this single variable aggregates a multitude of different actions that the firm can choose to take or not to take to hold its production costs down. Therefore, we do not seek a single proxy to replace $\delta$ in equation (13); instead we use proxies that represent different types of cost-controlling activities available to the subcontractor.

It is not easy to $f$ ind adequate proxies for the moral-hazard parameter. After all, moral hazard only arises because of the principal's inability to observe some variables; the principal's lack of knowledge is likely to be shared by any outside observer. The following proxies for moral hazard are available in the data. First, sometimes the principal purchases inputs on the contractor's behalf. This presumably has the effect of reducing moral hazard: if the subcontractor purchased the inputs himself, the price paid might vary depending on how much (costly) search the subcontractor undertook. Thus the method of obtaining inputs is one proxy for moral hazard. Second, the case studies of Asanuma (1984a, 1984b, 1985) suggest that moral hazard is more severe for labor inputs than materials inputs (because it is possible to economize on the amount of labor used, for example by adopting improved techniques, but there is little scope for economizing on the usage of 
materials inputs). Thus another proxy for moral hazard is the importance of labor in the production process, as measured by the subcontractor's wage bill as a fraction of his materials-inputs costs.

We used the following regression equation (based on (13)) to test the applicability of the model of Section 3:

$\ln \left(\frac{1}{\alpha}-1\right)=a_{0}+a_{1} \ln \left(\frac{1}{\sigma^{2}}\right)+a_{2} x_{2}+a_{3} x_{3}+a_{44} x_{4}+a_{5} x_{5}+\epsilon$.

Here $x_{2}$ represents the total sales of the subcontractor; $x_{3}$ represents the number of $f i r m s$ for which this firm subcontracts $\left(x_{2}\right.$ and $x_{3}$ are proxies for risk aversion: in a second regression we replace them with the estimated risk-aversion coefficient obtained in the previous section); $x_{4}$ represents the proportion of inputs secured by the subcontractor himself; $x_{5}$ represents its wage bill as a fraction of its materials-inputs costs $\left(x_{4}\right.$ and $x_{5}$ are proxies for the extent of moral hazard); and $\epsilon$ is a random variable. The theory predicts that all of the coefficients $a_{i}$ are strictly positive except the constant term $a_{0}$, which is predicted to be zero.

The independent variables in the estimation equation (14) can all be expected to be stochastic. The variance of costs was estimated from the data, as was the risk-aversion coefficient. All the other independent variables are proxies for either moral hazard or risk aversion; thus they include errors in addition to the true values of the represented variables. In an attempt to avoid possible bias in estimation we used the instrumental-variable method. Since no apparent extra variables were available for the instruments, we used as instruments the ranks of values of the independent variables (following Durbin (1954)). The results of the instrumental-variables estimations are reported in Table 3: Model I uses proxies for risk aversion, while Model II 
uses the estimated risk-aversion coefficients from Table 2.

(Ordinary-least-squares estimates and weighted-least-squares estimates of the same models, not reported here, produced results similar to Table 3.)

While using instrumental variables corrects the biassedness of the estimates resulting from the use of proxies, the estimates may not be fully efficient. Thus tests of hypotheses about the signs of the regression coefficients based on $t$-ratios should be interpreted with caution. Bearing this caveat in mind, from Table 3 we see that most of the regression coefficients have the predicted signs and are significant. (Asterisks denote significance at the 5 percent leve1). The exceptions are that one of the risk-aversion proxies in Model I (the number of parent firms) is insignificant; the constant term, which is predicted to be zero, is significantly positive in Model $\mathrm{I}$; and, in both models, the wage/material cost ratio, which is a moral-hazard proxy, is insignificant (evidently this is not an adequate proxy for moral hazard). Also, the coefficient of $\log \left(1 / \sigma^{2}\right)$, which is predicted to equal one, is clearly less than one in both models. (This prediction, however, unlike predictions about coefficient signs, is likely to be sensitive to the functional-form assumptions used in section 3.) Also, the model evidently does not capture all of the determinants of the contract (some of the likely omitted factors--the long-run nature of the relationships and competition for contracts--were discussed in section 5). Nevertheless, our empirical results show that the sharing parameter tends to be increasing in risk aversion and decreasing in moral hazard. Hence we can conclude that the regressions reported in Table 3 provide some evidence that the contracts in use in Japanese subcontracting reflect the principal-agent trade-off between moral hazard and risk sharing. 
Because of the data limitations, the analysis of this section should be regarded as a first pass at the question of econometrically implementing a principal-agent model of contract design. A more satisfactory test of the theory awaits the availability of detailed micro-data on contracts. Such a test could make use of the methods for testing principal-agent theory developed in this paper.

\section{The Welfare Costs of Informational Asymmetries}

Given the amount of effort directed in the last decade to incorporating informational asymmetries in microeconomic theory, it is pertinent to ask how significant these asymmetries are in the real world. How large are the welfare losses attributable to the incompleteness of information?

In the model of section 3 , the first-best amount of cost-controlling effort is extracted from the subcontractor when $\alpha=0$ (because in this case the subcontractor receives all of the benefits and incurs all of the costs of his own actions). The resulting effort, $\xi$, is equal to $\delta$ (from $(6)$ ). Hence, from (3), the first-best level of production cost (the level which would be attained if the principal could perfectly monitor the subcontractor's actions) is equal to $c^{*}+w-\delta$. From (9) and (6), the effort induced by the equilibrium contract is $\delta^{2} /\left(\delta+\lambda \sigma^{2}\right)$, so that the resulting production cost is $c^{*}+w-\delta^{2} /\left(\delta+\lambda \sigma^{2}\right)$. The difference between the lowest possible production cost and the realized production cost is therefore (using (9)) equal to $\delta \alpha ;$ or, in proportional terms, the difference is $\delta \alpha / c$.

We cannot directly estimate this cost difference because we do not have estimates of the moral-hazard parameter $\delta$. We can, however, provide a rough, illustrative calculation. Both Moore (1967) and Scherer (1964) concluded from their studies of United States military contracting that cost-plus contracts typically cost 10 percent more than fixed-price contracts. In our notation, 
this implies that $\delta / c$ approximately equals 0.1 . Other, indirect, evidence cited by McAfee and McMillan (1986, Ch. 6) suggests that $\delta / c$ can be as high as 0.2 .

Taking 10 to 20 percent as a plausible guess for the typical size of the moral-hazard effect, we conclude that the proportional excess production cost attributable to incomplete information is approximately $(0.1) \alpha$ to $(0.2) \alpha$. Using the average of our estimates of $\alpha$ (Table 1), this implies that realized production costs are higher than the lowest possible by an average about 7 percent (using the smaller moral-hazard figure) or about 14 percent (using the larger moral-hazard figure).

In a similarly speculative way, these numbers can also be interpreted as providing a lower-bound estimate of the costs of hierarchical control within a vertically-integrated firm. Since the large firm chose to contract out the work rather than do it in-house, we can presume that contracting out was the less costly option. If we assume that the large firm has access to the same production technology as the subcontractor, then the difference in costs between the large firm and the subcontractor is attributable to the costs of operating a hierarchy. (The sources of these costs of internal control have been examined by Geanakoplos and Milgrom (1985), Grossman and Hart (1984), and Williamson (1984).) The inefficiencies from the subcontractor's moral hazard, suggested in the previous paragraph to be between 7 percent and 14 percent of production cost, must be smaller than the inefficiencies of controlling a vertically-integrated firm.

\section{Discussion of the Empirical Results}

This paper's interpretation of the subcontracting relationship is opposite to the traditional view of Japanese subcontracting, which sees the principal as using his monopsony power to exploit the subcontractor, in particular by 
forcing the subcontractor to bear the risk of cost and demand fluctuations: the large firms are viewed as using their subcontractors as buffers to shield themselves from risk. ${ }^{15}$ since we have estimated the sharing parameters to be markedly greater than zero, we conclude that the large firms are in fact absorbing risk on behalf of the subcontractors.

The observation that, in a recession, large firms reduce the amount of work they contract out is often cited as evidence in favor of the buffering hypothesis. This observation does not, however, contradict the results of this paper: on the contrary, it can be explained simply, without reference to attitudes towards risk. When final demand falls in a recession and, as a result, the large firm's fixed labor force becomes idle, its opportunity cost of internal production falls; hence internal production becomes more profitable relative to subcontracting (McAfee and McMillan (1986b)).

According to Williamson (1984), exchanges that take place within a firm are characterized by what he called "low-powered incentives": individuals are faced with little responsibility for the consequences of their actions. Market transactions, in contrast, use "high-powered incentives". In the terminology of the present paper, incentives are low-powered or high-powered as $\alpha$ is close to one or close to zero. However, contrary to Williamson's analysis, the market transactions between Japanese subcontractor and principal appear to be more low-powered than high-powered, in that the computed $\alpha$ 's reported in Table 1 are typically closer to one than to zero.

Incentive contracts, with a sharing parameter a typically between 0.5 and 0.9 , are increasingly often used by the U.S. Department of Defense in its weapons acquisition. On the basis of a more general version of the model of Section 3, McAfee and McMillan (1986a) advocated that other government departments switch from using fixed-price or cost-plus contracts to using incentive contracts as a means of lowering procurement costs. By showing that 
the private sector finds it in its interest to use incentive contracts, the present study gives extra weight to the argument that governments should use them.

\section{Conclusions}

Since the early $1970^{\prime} s$, a large amount of theoretical work has been directed at constructing and refining principal-agent theory. The foregoing analysis presented what is, to our knowledge, the first empirical test of a fully-specified principal-agent model. 16

Subject to caveats due to the unavoidable limitations of the available data, the empirical analysis showed the following. First, the subcontractors are risk averse. Second, the contracts in use have the principal absorbing some of the risk of unpredictable cost fluctuations on behalf of the subcontractor. Third, consistently with the principal-agent model of section 3, the price paid adjusts more to changes in the subcontractor's production costs (i) the more risk averse the subcontractor is; (ii) the bigger the fluctuations in costs are; and (iii) the less severe moral hazard is. Although in fact the price adjustments are based on a vector of cost components (as shown by the case studies of Asanuma (1984a, 1984b, 1985)), it is as if the price adjustments were determined by a sharing of total cost changes (as in the model of section 3). Thus the contracts in use in Japanese subcontracting can be interpreted as resolving the principal-agent tradeoff between risk sharing and moral hazard. Principal-agent theory appears to be consistent with the data.

The subcontractors' estimated coefficients of absolute risk aversion decrease as $\mathrm{firm}$ size increases; all of the subcontractors are significantly risk averse. The calculated sharing parameters for different industries and firm sizes range from 0.39 to 0.89 . 
Appendix: Data Sources and Construction

The raw data are as follows:

I. Census of Manufactures (Firm Series) (from MITI (1973-1982)):

C1. No. of Firms

C2. No. of Employees

C3. Total Wages (million yen)

C4. Total Shipments (million yen)

C5. Gross Value Added (million yen)

C6. Depreciation (million yen)

II. Surveys of Industries (from MITI (1981)):

s1. No. of Firms

S2. Sales per Firm (million yen)

S3. Subcontracting Firms (\%)

S4. No. of Parent-Firms per Subcontractor

S5. Value of subcontracting per subcontractor (10 thousand yen)

S6. Independent Securing of Materials (\%)

S7. Firms with outside orders (\%)

58. Value of Outside Orders per Firm with Outside Orders (yen) 
The data used in the paper were constructed from the raw data as follows:

v1. Profit per Firm $=(C 5-C 3-C 6) / C 1$

adjusted by the wholesale price index $(1981=100)$

v2. Mean of Profit $=\frac{1}{10} \sum_{t=1}^{10} \mathrm{v} 1(t)$

v3. Variance of Profit $=\frac{1}{10} \sum_{t=1}^{10}\left(v_{1}(t)-v_{2}\right)^{2}$

V4. Cost per Firm $=(\mathrm{C4}-\mathrm{C5}+\mathrm{C} 3+\mathrm{C6}) / \mathrm{Cl}$

v5. Mean of cost $=\frac{1}{10} \sum_{t=1}^{10} v_{4}(t)$

v6. Variance of cost $=\frac{1}{10} \sum_{t=1}^{10}(\mathrm{~V} 4(t)-\mathrm{v} 5)^{2}$

Risk aversion proxies:

v7. Total Sales $=$ s2

v8. Numbers of Parent-Firms per Firm $=(\$ 3 \times S 4) / 100$

Moral hazard proxies:

v9. Independent Securing of Materials $=\mathbf{S 6}$

v10. Proportion of Outside Order in Sales $=(57 \times 58) /(100 \times 52)$

v11. Wages/Material Costs $=\mathrm{C} 3 /(\mathrm{C4}-\mathrm{C5})$

Note from the above that the sample variances of cost and profit were computed using time series of 10 years' annual data. 


\section{References}

Allen, G. C. The Japanese Economy (New York: St. Martin's Press, 1981). Aoki, Masahiko. "Aspects of the Japanese Firm". In The Economic Analysis of the Japanese Firm, edited by M. Aoki. Amsterdam: North-Holland, 1984a.

Aoki, Masahiko. "Innovative Adaption through the Quasi-Tree Structure: An Emerging Aspect of Japanese Entrepreneurship." Zeitschrift fuer Nationaloekonomie, Supplementum 4 (1984b): 177-198.

Aoki, Masahiko. "Learning by Doing vs the Bounded-Rational Control:

An Approach to U.S.-Japan Comparison of Industrial Organization." Mimeo, Stanford University, May 1985.

Asanuma, B. "The Structure of Parts Transactions in Japan-The Case of the Automobile Industry." (in Japanese). Keizaironso 133.3 (March 1984a): $137-158$.

Asanuma, B. "The Structure of Parts Transactions in the Automobile Industry -the Mechanism of Adjustments and Innovative Adaptation." (in Japanese). Gendaf Keizai 59 (Summer 1984b): 38-48.

Asanuma, B. "Transactional Structure of Parts Supply in the Japanese Automobile and Electric Machinery Industries: A Comparative Analysis," Technical Report No. 1, Socio-Economic Systems Research Project, Kyoto University, July 1985.

Caves, Richard E., and Uekusa, Masu. Industrial Organization in Japan Washington: Brookings, 1976.

Chandler, Alfred D. The Visible Hand, Cambridge, Mass: Harvard University Press, 1977.

Coase, R. H. "The Nature of the Firm." Bconomica 4 (November 1937): 386-405. 
Dore, R. "Goodwill and the Spirit of Market Capitalism." British Journal of Sociology 34 (December 1983): 459-482.

Durbin, J. "Errors in Variables." Review of the International statistics Institute 1 (1954): 23-32.

Easterbrook, Frank H. "Insider Trading as an Agency Problem." In Principals and Agents, edited by J.W. Pratt and R. Zeckhauser (Boston: Harvard Business School Press, 1985).

Geanakoplos, J., and Milgrom, P. "A Theory of Hierarchies Based on Limited Managerial Attention." Discussion Paper No. 775, Cowles Foundation, Yale University, October 1985.

Grossman, S., and Hart, 0 . "The Costs and Benefits of Ownership: A Theory of Vertical Integration," mimeo, London School of Economics, March 1984.

Holmstrom, Bengt, and Milgrom, Paul. "Aggregation and Linearity in the Provision of Intertemporal Incentives." Working Paper No. 5, Yale School of Organization and Management, 1985.

Imai, Ken-Ichi and Itami, Hiroyuki. "Interpretation of Organization and Market: Japan's Firm and Market in Comparison with the U.S." International Journal of Industrial Organization 2 (December 1984): 285-310.

Kawasaki, Seiichi, McMillan, John, and Zimmermann, Klaus F. "Inventories and Price Inflexibility." Econometrica 51 (May 1983): 599-610.

Lewis, Tracy R. "Bonuses and Penalties in Incentive Contracting." Bell Journal of Economics 11 (Spring 1980): 292-301.

Lim, Chin. "Theory of the Firm: Uncertainty and the Choice of Experiments." Journal of Economic Theory 24 (June 1981): 328-361. 
MacDonald, Glenn M. "New Directions in the Economic Theory of Agency." Canadian Journal of Economics 17 (August 1984): 415-440.

McAfee, R. Preston, and McMillan, John. "Bidding for Contracts: A Principal-Agent Analysis." mimeo, University of Western Ontario, June 1985.

McAfee, R. Preston, and McMillan, John. Incentives in Government Contracting, Toronto: University of Toronto Press, 1986a, to be published.

McAfee, R. Preston, and McMillan, John. "Strategic Vertical Integration." Mimeo, University of Western Ontario, February $1986 \mathrm{~b}$.

McMillan, John, and Morgan, Peter B. "Price Dispersion, Price Flexibility, and Consumer Search." mimeo, University of Western Ontario, June 1985. Ministry of International Trade and Industry, Census of Manufactures (in Japanese: Kogyo Tokei Hyol, annually 1973-1982.

Ministry of International Trade and Industry, Survey of Industrial Situations (in Japanese: Kogyo Jittai Chosa), Tokyo 1981.

Ministry of International Trade and Industry, Annual Report on Small Enterprises (in Japanese: Chusho-Kigyo Hakusho) Tokyo 1984.

Moore, F. T. "Incentive Contracts." In Defense Management, edited by S. Enke. Englewood Cliffs, N.J.: Prentice-Hall, 1967.

Nakatani, Iwao. "The Economic Role of Financial Corporate Grouping." in The Economic Analysis of The Japanese Firm ed. by M. Aoki, NorthHolland, 1984.

Okazaki, Keiko. "An Empirical Analysis of Subcontracting Firms" (in Japanese). Gendai-Keizai 58 (Summer 1984): 49-58.

Okun, Arthur. Prices and Quantities: A Macroeconomic Analysis. The Brookings Institution: Washington D.C. 1981. 
Ouchi, William G. Theory z: How American Buslness Can Meet the Japanese Challenge. New York: Avon 1982.

Scherer, Frederic M. "The Theory of Contractual Incentives for Cost Reduction." Quarterly Journal of Economics 78 (March 1964): 257-280. Williamson, Oliver E. Markets and Hierarchies: Analysis and Antitrust Implications. New York: Free Press 1975.

Williamson, Oliver E. "Transaction-Cost Economics: The Governance of Contractual Relations." Journal of Law and Economics 22 (October 1979): 233-261.

Williamson, Oliver E. "The Incentive Limits of Firms: A Comparative Institutional Assessment of Bureaucracy." Weltwirtschaftliches Archiv 12 (1984): 736-762.

Wilson, Robert. "Reputations in Games and Markets." Technical Report No. 434, IMSSS, Stanford University, November 1983.

Yokokura, N. "Chushokigyo" ("Small Business"). In Nihon No Sangyo Seisaku (Japanese Industrial Policy), edited by R. Komiya, M. Okuno, and S. Suzamura (Tokyo: Tokyo University Press, 1984). 
TABLE 1

ESTIKATES OF THE SHARING PARAIIETER, $\alpha$

\section{FIRM SIZE (NULABER OF EMPLOYEES)}

$\begin{array}{llllll}\text { INDUSTRY } & 20-29 & 30-49 & 50-99 & 100-199 & 200-299 \\ \text { Textiles } & .39364 & .70613 & .66058 & .71151 & .58764 \\ \text { Clothing } & .46745 & .45526 & .69573 & .65585 & .61073 \\ \text { Iron and Steel } & .73038 & .81134 & .85470 & .70732 & .50367 \\ \text { Nonferrous Metals } & .81850 & .79304 & .76396 & .74036 & .80177 \\ \begin{array}{l}\text { Metal Products } \\ \text { Machinery }\end{array} & .52832 & .73231 & .76916 & .73596 & .61371 \\ \begin{array}{l}\text { Electrical Machinery } \\ \text { and Equipment }\end{array} & .74937 & .82890 & .86674 & .83965 & .81335 \\ \begin{array}{l}\text { Transportation } \\ \text { Equipment }\end{array} & .51280 & .65280 & .78422 & .75241 & .79069 \\ \text { Precision Instruments } & .52321 & .74750 & .75331 & .81646 & .79589 \\ \end{array}$


TABLE 2

ESTIMATES OF RISK AVERSION

ESTIMATED COEFFICIENT

\section{FIRM SIZE}

(NUMBER OF EMPLOYEES) $\lambda / 2$ (standard error)

20-29

$$
0.15225^{*}
$$$$
(0.02865)
$$

$30-49$

$$
0.06671^{*}
$$

$(0.007154)$

$50-99$

$$
\begin{aligned}
& 0.00802^{*} \\
& (0.002465)
\end{aligned}
$$

$100-199$

$$
\begin{aligned}
& 0.00154^{*} \\
& (0.0005650)
\end{aligned}
$$

200-299

$$
\begin{aligned}
& 0.00144^{*} \\
& (0.0002527)
\end{aligned}
$$

$\mathbf{k}$

$$
\text { (standard error) }
$$

$$
48.782^{*}
$$$$
(5.14074)
$$

$$
76.594^{\star}
$$

0.8268

$(5.39432)$

$$
175.46^{*}
$$

0.3474

$(20.1380)$

$$
393.1 .1^{*}
$$

0.2632

$(40.5770)$

$$
701.76^{*}
$$

0.6361

Adjusted $\mathbf{R}^{2}$

0.6022

(75.6647)

*Significant at the 5 percent level. 
TABLE 3

TESTING THE PRINCIPAL-AGENT MODEL

Independent Variable

o. CONSTANT'

1. $\operatorname{LN}(1 / \operatorname{VAR}(\operatorname{COST}))$

2. SALES (X 100,000)

3. NO. OF PARENT FIRMS

$2^{\cdot} . \operatorname{LN}(1 /$ LAMBDA $)$

4. MATERIALS SECURING

5. WAGE/MATERIALS COST

Adjusted $\mathrm{R}^{2}$

Number of observations $=45$

*Significant at the 5 percent level.

\section{Instrumenta1-Variable Estimates}

(standard error)

Mode1 I

2.1139*

(1.0066)

$0.5100 *$

$(0.1298)$

$0.6628^{*}$

$(0.1933)$

$-0.0420$

$(0.0329)$

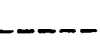

$0.0489^{*}$

$(0.0156)$

$-0.6015$

(1.0609)

0.4754
0.3405

Model II

$$
\begin{gathered}
0.8178 \\
(0.7435) \\
0.3978^{\star} \\
(0.1034)
\end{gathered}
$$

$$
\begin{array}{r}
0.3186^{*} \\
(0.0981)
\end{array}
$$

$0.2720^{*}$
$(0.0110)$

$-1.2483$

(1.1634) 


\section{Footnotes}

*We thank Robin Carter, Glenn MacDonald, Preston McAfee, Peter Morgan, Aman U1lah, and Michael Veall for useful comments, Banri Asanuma for information on Japanese subcontracting practices, and $\mathrm{K}$. Kozuka for research assistance. This research was begun while McMillan was visiting the Institute of Economic Research, Kyoto University. McMillan's research was supported by the Social Sciences and Humanities Research Council of Canada.

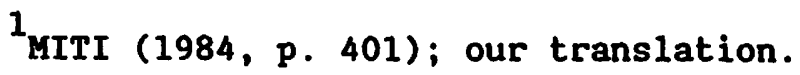

2Dore (1983, p. 468), Aoki (1985, p. 4). For further evidence that subcontracting is more prevalent in Japan than elsewhere, see Aoki (1984a) and MITI (1984).

${ }^{3}$ The percentage of small firms (defined to be firms with less than 300 employees) doing subcontracting was 58.7 in $1971,60.7$ in 1976 , and 65.5 in 1981 (MITI (1984, p. 391)).

4illiamson (1979) also discussed an intermediate category of transactions.

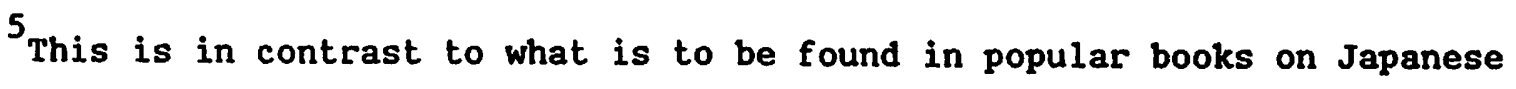
business practices, such as: "In a Japanese auto plant...the relationship between the major auto firm and its satellite suppliers is one of total cooperation" (Ouchi, 1982, p. 17).

${ }^{6}$ This is Theorem 7 of Holmstrom and Milgrom (1985). The model described above is the one--dimensional Brownian model of section 4 of the Holmstrom-Milgrom paper. 
7

The cost-controlling technology must be strictly convex, so that there are diminishing returns to effort, because otherwise the subcontractor would be able by exerting sufficient effort to make his production costs negative. Equation (4) gives the most general quadratic form for $h$, since it can be assumed without loss of generality that $h(0)=0$ (since any nonzero $h(0)$ could be added to $c^{*}$ ); and it must be that $h^{\prime}(0)=0$ in order to avoid a discontinuity at $\alpha=1$.

${ }^{8}$ On equilibrium inventory decisions, see Kawasaki, McMillan, and Zimmermann (1983).

9roof: Using $\mathrm{E}$ to denote the expectations operator, the principal's expected payment is (from putting $\mu=E \pi$ in (5), then substituting for $b$ in (2) and using (3)):

$$
E p=\mu+c^{*}+h(\xi)-\xi \text {. }
$$

The principal chooses a to minimize Ep subject to two constraints. First, the subcontractor's expected utility of profit EU( $\left.\pi_{i}\right)$ is no less than his expected utility from his best alternative activity, which is taken to be constant. Using (7) and (8), this is equivalent to $\mu \geq 2 / 2 \lambda(1-\alpha)^{2} \sigma^{2}+a$, where $a$ is a constant, a function of the subcontractor's expected utility from alternative activities. Since the principal's expected payment Ep is increasing in the subcontractor's expected profit $\mu$, the inequality sign in this constraint can be replaced without loss of generality by an equality sign. The second constraint is that the subcontractor will respond by choosing his own best effort level, as shown by (6). Choosing a to maximize expected payment (as given above) subject to these two constraints and using (4) yields (9), as required. Once $\alpha$ is determined, then the other parameter of the payment function, $b$, is also determined (from (2), (3), and the above equality constraint on $\mu$ ). 
${ }^{10}$ The facts on which this section is based come in part from Asanuma (1984a, 1984b, 1985), and in part from personal communications with Professor Asanuma.

${ }^{11}$ One unavoidable drawback of the available data is that not all of the firms within each category actually do subcontracting. In the industries we considered, at least 60 percent of the firms are subcontractors.

${ }^{12}$ See also Okazaki (1984) for estimates of Japanese firms' risk aversion and of barriers to entry. Nakatani (1984) investigated risk sharing within Japanese corporate groups.

${ }^{13}$ In order to obtain larger sample sizes, we included in the risk-aversion estimations some industries whose firms were not predominantly subcontractors. Thus 19 industries are included here, compared with 9 in the estimations of Sections 5 and 7 .

${ }^{14}$ Note that the fact that reported profits are accounting profits, not economic profits, does not invalidate the following test of principal-agent theory. All that is used in that test is the variance of costs and profits: provided that accounting and economic profits are closely correlated, the variance estimates are unaffected by the accounting/economic profit distinction.

${ }^{15}$ On the traditional view, see for example Allen (1981, p. 122), Caves and Uekusa (1976, pp. 112-115), and the references therein. A critique of the traditional view on a priori grounds was provided by Aoki (1984a, 1984b).

${ }^{16}$ Easterbrook (1985, p. 81) remarked of agency theory that: "The complications in the theory would not be troubling if there were good tests of the predictions of these models. There are not, however, and the agency literature is one of the few remaining parts of economic thought that depends a]most entirely on the power of deductive logic." 
8401C Harrison, Glenn W. and Manning, Richard. BEST APPROXIMATE AGGREGATION OF INPUT-OUTPUT SYSTEMS.

8402C Parkin, Michael. CORE INFLATION: A REVIEW ESSAY.

8403C Blomqqist, Ảke, and McMahon, Gary. SIMULATING COMMERICAL POLICY IN A SMALL, OPEN DUAL ECONOMY WITH URBAN UNEMPLOYMENT: A GENERAL EQUILIBRIUM APPROACH.

8404C Wonnacott, Ronald. THE THEORY OF TRADE DISCRIMINATION: THE IIRROR IMAGE OF VINERIAN PREFERENCE THEORY?

8405C Whalley, John. IMPACTS OF A 50\% TARIFF REDUCTION IN AN EIGHT-REGION GLOBAL TRADE MODEL.

8406C Harrison, Glenn W. A GENERAL EQUILIBRIUM ANALYSIS OF TARIFP REDUCTIONS.

8407C Horstmann, Ignatius and Markusen, James R. STRATEGIC INVESTMENTS AND THE DEVELOPMENT OF MULTINATIONALS.

8408C Gregory, Allan $W$. and McCurdy, Thomas H. TESTING THE UNBIASEDNESS HYPOTHESIS IN THE FORWARD FOREIGN EXCHANGE MARKET: A SPECIFICATION ANALYSIS.

8409C Jones, Ronald $w$. and Klerzkowsk1, Henryk. NEIGHBORHOOD PRODUCTION STRUCTURES WITH APPLICATIONS TO THE THEORY OF INTERNATIONAL TRADE.

8410C Weller, Paul and Yano, Makoto. THE ROLE OF FUTURES MARKETS IN INTERNATIONAL TRADE: A GENERAL EỌUIL IBRIUM APPROACH.

8411C Brecher, Richard A. and Bhagwat1, Jagdish N. VOLUNTARY EXPORT RESTRICTIONS VERSUS IMPORT RESTRICTIONS: A WELFARE-THEORETIC COMPARISON.

8412C Ethier, Wilfred J. ILLEGAL IMMIGRATION.

8413C Eaton, Jonathon and Gene M. Grossman. OPTIMAL TRADE AND INDUSTRIAL POLICY UNDER OLIGOPOLY.

$8414 \mathrm{C}$ Hooton, Ian. PREFERENTIAL TRADING AGREEMENTS - A 3xn MODEL.

8415C Parkin, Michael. DISCRIMINATJNG BETWEEN KEYNESIAN AND CLASSICAL TIEORIES OF THE BUSINESS CYCLE: JAPAN $1967-1982$

8416C Deardorff, Alan V. FIRless FIRwoes: HOW PREFERENCES CAN INTERFERE WITH THE THEOREMS OF INTERNATIONAL TRADE.

8417C Greenwood, Jeremy. NONTRADED GOODS, THE TRADE BALANCE, AND THE BALANCE OF PAYRENTS. 
8418C Blomqvist, Ake and Sharif Mohammad. CONTROLS, CORRUPTION, AND COMPETITIVE RENT-SEEKING IN LDCS.

8419C Grossman, Herschel I. POLICY, RATIONAL EXPECTATIONS, AND POSITIVE ECONOMIC ANALYSIS.

8420C Garber, Peter M. and Robert G. King. DEEP STRUCTURAL EXCAVATION? A CRITIỌUE OF EULER EQUATION METHODS.

8421C Barro, Robert J. THE BEHAVIOR OF U.S. DEFICITS.

8422C Persson, Torsten and Lars E.0. Svensson. INTERNATIONAL BORROWING AND TIME-CONSISTENT FISCAL POLICY.

8423C. Obstfeld Maurice. CAPItAl controls, tHe DUAL exchange RATE, AND DEVALUATION.

8:24C Kuhn, Peter. UNION PRODUCTIVITY EFFECTS AND ECONOMIC EFFICIENCY.

8425C Hamilton, Bob and John whalley. TAX TREATMENT OF HOUSING IN A DYNAMIC SEOUENCED GENERAL EOUUILIBRIUM MODEL.

$\because 4$ 26C Hamilton, Bob, Sharlf Mohammad, and John Whalley. RENT SEEKING AND THE NORTH-SOUTH TERMS OF TRADE.

8427C Adams, Charles and Jeremy Greenwood. DUAL EXCHANGE RATE SYSTEMS AND CAPITAL CONTROLS: $\Lambda$ N INVESTIGATION.

3428 Loh, Choon Cheong and Michael R. Veall. A NOTE ON SOCIAL SECURITY AND PRIVATE SAVINGS IN SINGAPORE.

8429 Whalley, John. REGRESSION OR PROGRESSION: THE TAXING OUESTION OF INCIDENCE ANALYSIS.

3430 Kuhn, Peter. WAGES, EFFORT, AND INCENTIVE-COMPATIBILITY IN LIFE-CYCLE EMPLOYMENT CONTRACTS.

8431 Greenwood, Jeremy and Kent P. Kimbrough. AN INVESTIGATION IN THE THEORY OF FOREICN EXCHANGE CONTROLS.

8432 Greenwood, Jeremy and Kent P. Kimbrough. CAPITAL CONTROLS AND THE INTERNATIONAL TRANSMISSION OF FISCAL POLICY.

8433 : Nguyen, Trien Trien and John Whalley. EỌUILIBRIUM UNDER PRICE CONTROLS WITH ENDOGENOUS TRANSACTIONS COSTS.

8434 Adams, Charles and Russell S. Boyer. EFFICIENCY AND A SIMPLE MODEL OF EXCHANGE RATE DETERMINATION. 
8435 Kuhn, Peter. UNIONS, ENTREPRENEURSH IP, AND EFFICIENCY.

8436 Hercowitz, Zvi and Efraim Sadka. ON OPTTMAL CURRENCY. SUBSTITUTION POLICY AND PUBLIC PINANCE.

8437 Lenjosek, Gordon and John Whalley, POLICY EVALUATION IN A SMALL OPEN PRICE TAKING ECONOMY: CANADIAN ENERGY POLICIES.

8438 Aschauer, David and Jeremy Greenwood. MACROECONOMIC EFFECTS OF FISCAL POLICY.

8439C Hercowitz, Zvi. ON THE DETERMINATION OF THE EXTERNAI DEBT: THE CASE OF ISRAEL.

8440C Stern, Robert M. GLOBAL DIMENSIONS AND DETERMINANTS OF INTERNATIONAL TRADE AND INVESTMENT IN SERVICES.

8441C Deardorff, Alan v. COMPARATIVE ADVANTAGE AND INTERNATIONAL TRADE AND INVESTMENT IN SERVICES.

8442C Daly, Donald J. TECHNOLOGY TRANSFER AND CANADA'S COMPETITIVE PERFORMANCE.

8443C Grey, Rodney de C. NEGOTIATING ABOUT TRADE AND INVESTMENT IN SERVICES.

8444C Grossman, Gene $M$. and Carl Shapiro. NORMATIVE ISSUES RAISED BY INTERNATIONAL TRADE IN TECHNOLOGY SERVICES.

3445C Chant, John F. THE CANADIAN TREATMENT OF FOREIGN BANKS: A CASE STUDY IN THE WORKINGS OF THE NATIONAL TREATMENT APPROACH.

8446C Aronson, Jonathan D. and Peter F. Cowhey. COMPUTER, DATA PROCESSING, AND COMMUNICATION SERVICES.

8447C Feketekuty, Geza. NEGOTIATING STRATEGIES FOR LIBERALIZING TRADE AND INVESTMENT IN SERVICES.

8448C Harrison, Glenn, W. and E.E. Rutstrom. THE EFFECT OF MANUFACTURING SECTOR PROTECTION ON ASEAN AND AUSTRALIA: A GENERAL ENUILIBRIUM ANALYSIS. 
8501C Greenwood, Jeremy and Kent P. Kimbrough. FOREIGN EXCHANGE CONTROLS IN A BLACK MARKET ECONOMY.

8502C Horstmann, Ignatius and James R. Markusen. UP YOUR AVERAGE COST CURVE: INEFFICIENT ENTRY AND THE NEN PROTECTIONISM.

8503C Gregory, Allan $W$. TESTING INTEREST RATE PARITY AND RATIONAL EXPECTATIONS TOR CANADA AND THE UNITED STATES.

8504C Kuhn, Peter and Ian Wooton. INTERNATIONAL FACTOR MOVEMENTS IN THE PRESENCE OF A FIXED FACTOR.

8505C Wong, Kar-y1u. GAINS FROM GOODS TRADE AND FACTOR MOBILITY.

8506C Weller, Paul and Makoto Yano. FUTURES MARKETS, REAL INCOME, AND SPOT PRICE VARIABILITY: A GENERAL EỌUIIIBRIUM APPROACH.

8507C Diewert, H.E. THE EFFECTS OF AN INNOVATION: A TRADE THEORY APPROACH.

8508C Ethier, Wilfred J. FOREIGN DIRECT INVESTMENT AND THE MULTINATIONAL FIRM.

8509C Dinopoulos, Elias. INSIDE THE BLACK BOX: (IN)TANGIBLE ASSETS, INTRA-INDUSTRY INVESTMENT AND TRADE.

8510C Jones, Richard, John Whalley, and Randall Higle. REGIONAL IMPACTS OF TARIFFS IN CANADA: PRELIMINARY RESULTS FROM A SMALL DIMENSIONAL NUMERICAL GENERAL EOUUIL IBRIUM MODEL.

8511C Whalley, John. HIDDEN CHALLENGES IN RECENT APPLIED GENERAL EQQUIL IBRIUM EXERCISES.

8512C Smith, Bruce. SOME COLONIAL EVIDENCE ON TWO THEORIES OF MONEY: MARVLAND AND THE CAROLINAS.

8513C Grossman, S.J., A. Melino, and R.J. Shiller. ESTIMATING THE CONTINUOUS TIME CONSUMPTION BASED ASSET PRICING MODEL.

8514C Romer, Paul R. TAX EFFECTS AND TRANSACTION COSTS FOR SHORT TERM MARKET DISCOUNT BONDS.

8515C McCallum, Bennett T. ON CONSEOUENCES AND CRITJCISMS OF MONETARY TARGETING.

8516C Dinopoulos, Elias and Ian Wooton. A NORTH-SOUTH MODEL OF INTERNATIONAL JUSTICE.

8517C Huffman, Gregory W. A DYNAMIC EQUILIBRIUM MODEL OF ASSET PRICES AND TRANSACTION VOLUME.

8518C Huffman, Gregory W. AN ALTERNATIVE VIEW OF OPTIMAL SEIGNIORAGE.

8519C Huffman, Gregory W. ASSET PRICING WITH HETERGENEOUS ASSETS. 
8520C Hercowitz, Zvi. THE REAL INTEREST RATE AND AGGREGATE SUPPLY.

8521C Davies, James and Michael Hoy. COMPARING INCOME DISTRIBUTIONS UNDER AVERSION TO DOWNSIDE INEQUALITY.

8522C Nguyen, Trien T. and John Whalley. COEXISTENCE OF EQUILIBRIA ON BLACK AND WHITE MARKETS.

8523C Clarete, Ramon and John Whalley. INTERACTIONS BETWEEN TRADE POLICIES AND DOMESTIC DISTORTIONS: THE PHILIPPINE CASE.

8524C Hamilton, Bob, Sharif Mohammad, and John Whalley. APPLIED GENERAL EQUILIBRIUM ANALYSIS AND PERSPECTIVES ON GROWTH PERFORMANCE.

8525C Huffman, Gregory W. THE LAGGED EFFECTS OF POLICY ON THE PRICE LEVEL.

8526C Laidler, David. FISCAL DEFICITS AND INTERNATIONAL MONETARY INSTITUTIONS.

8527C Goodfriend, Marvin. MONETARY MYSTIQUE: SECRECY AND CENTRAL BANKING.

8528C Nguyen, Trien $T$. and John Whalley. GENERAL EQUILIBRIUM ANALYSIS OF PRICE CONTROLS A TWO-SECTOR COMPUTATIONAL APPROACH.

8529C Heckman, James J, and V. Joseph Hotz. AN INVESTIGATION OF THE LABOR MARKET EARNINGS OF PANAMANIAN MALES: EVALUATING SOURCES OF INEQUALITY.

8530C Greenwood, Jeremy and Gregory W. Huffman. A DYNAMIC EQUILIBRIUM MODEL OF INFLATION AND UNEMPLOYMENT.

8531C Freeman, Scott. INSIDE MONEY, MONETARY CONTRACTIONS, AND WELFARE.

8532C Paderanga, Cayetano Jr. and Ian Wooton. A POSITIVE VIEW OF INFANT INDUSTRIES.

$8533 \mathrm{C}$ St-Hilaire, France and John Whalley. A MICROCONSISTENT DATA SET FOR CANADA FOR USE IN REGIONAL GENERAL EQUILIBRIUM POLICY ANALYSIS.

8534C Whalley, John. OPERATIONALIZING WALRAS: EXPERIENCE WITH RECENT APPLIED GENERAL EQUILIBRIUM TAX MODELS.

8535C Melvin, James R. THE GENERAL NON-EQUIVALENCE OF TARIFFS AND IMPORT QUOTAS. 
8601C Greenwood, Jeremy and R. Preston McAfee. EXTERNALITIES AND ASYMMETRIC INFORMATION.

8602C Dinopoulos, Elias and Mordecha1 E. Kreinin. IMPORT QUUOTAS AND VERS: A COMPARATIVE ANALYSIS IN A THREE-COUNTRY FRAMEWORK.

8603C Clarete, Ramon and John Whalley. COMPARING THE MARGINAL WELFARE COSTS OF COMMODITY AND TRADE TAXES.

8604C Wigle, Randy. CANADIAN TRADE LIBERALIZATION: SCALE ECONOMIES IN A GLOBAL CONTEXT.

8605C Parkin, Michae1. DOMESTIC MONETARY INSTITUTIONS AND FISCAL DEFICITS.

8606C Dinopoulos, Elias and Ian Wooton. INTERNATIONAL TRADE AND THE ACOUUISITION OF SKILLS.

8607C Kawasaki, Seiichi and John McMillan. THE DESIGN OF CONTRACTS: EVIDENCE FROM JAPANESE SUBCONTRACTING. 